\title{
Indigenous Plasmids from Phytopathogenic Corynebacterium Species
}

\author{
By DENNIS C. GROSS, ANNE K. VIDAVER \\ AND MICHAEL B. KERALIS \\ Department of Plant Pathology, University of Nebraska, \\ Lincoln, Nebraska 68583, U.S.A.
}

(Received 2 February 1979)

\begin{abstract}
Efficient and reproducible cell lysis and the isolation of plasmid DNA from nine phytopathogenic Corynebacterium species is described. One to three plasmids, ranging from 23 to 77 megadaltons, were recovered from each strain, as detected by comparative agarose gel electrophoresis. Corynebacterium michiganense showed considerable plasmid diversity. Other species, such as $C$. nebraskense and $C$. insidiosum, did not. Bacteriocin production, colony morphology, pigmentation and virulence were not correlated with the presence of plasmids. Sedimentation through neutral and alkaline sucrose gradients and electrophoretic separation on agarose gels gave similar values for plasmid molecular weights. Log-linear alkaline sucrose gradients proved useful for molecular weight determinations and also for the isolation of purified plasmids on a preparative scale.
\end{abstract}

\section{INTRODUCTION}

The phytopathogenic Corynebacterium species are a diverse physiological, morphological and pathological group of Gram-positive bacteria that cause agronomically important diseases (Starr et al., 1975; Vidaver \& Starr, 1979). Under natural conditions, Corynebacterium species are generally host-specific and cause diseases of distinct symptomatology (Lelliott, 1966). Serology (Lazar, 1968), phage sensitivity (Echandi \& Sun, 1973) and bacteriocin production (Gross \& Vidaver, 1979) have all been used to differentiate species and strains of phytopathogenic corynebacteria. The ubiquity of bacteriocin production by 7 out of 12 phytopathogenic Corynebacterium species (Gross \& Vidaver, 1979) and the general association of bacteriocin production by Gram-positive bacteria with plasmid DNA (Tagg et al., 1976) suggested a similar relationship may exist in corynebacteria. Indeed, strains of streptococci, clostridia and bacilli that lose plasmids often lose bacteriocin production (Tagg et al., 1976). However, there have been no reports of plasmids in Corynebacterium species including those of animal, plant or saprophytic origin.

Currier \& Nester (1976) reported a procedure for isolating both small and large [ $>100$ megadalton (Mdal)] plasmids from Gram-negative bacteria. Plasmid enrichment involved denaturing sheared chromosomal DNA with alkali and selectively removing denatured DNA by salt precipitation in the presence of phenol. Chassy et al. (1976) used this method of plasmid isolation and developed a lysis procedure suitable for Gram-positive lactobacilli. Plasmid size determinations may be made by sedimentation through alkaline or neutral sucrose gradients (Nuti et al., 1977; Shipley \& Olsen, 1975). However, Meyers et al. (1976) found agarose gel electrophoresis to be a rapid and economical means of surveying molecular weights of plasmid DNA. All of the above techniques were adapted and used in this study.

We report here a survey of strains from several phytopathogenic Corynebacterium species for the presence of plasmids. While the presence of plasmids and bacteriocin production were not associated, the number and molecular weight of plasmids detected revealed differences in DNA content in otherwise indistinguishable strains. 


\section{METHODS}

Bacterial strains. Corynebacterium species and strain designations along with their plant host of origin are listed in Table 1. Escherichia coli strain J53(RP1) was provided by R. Olsen (University of Michigan, Ann Arbor, Mich., U.S.A.) and strains J53(RSF1030) and J53(R1drd19) by S. Falkow (University of Washington, Seattle, Wash., U.S.A.).

Cultivation of bacteria. Strains of corynebacteria were maintained on a nutrient broth/yeast extract (NBY) agar medium (Vidaver, 1967) as previously described (Gross \& Vidaver, 1979). Escherichia coli strains were maintained on NBY agar containing either $25 \mu \mathrm{g}$ tetracycline $\mathrm{ml}^{-1}$ [J53(RP1)], $25 \mu \mathrm{g}$ neomycin $\mathrm{ml}^{-1}$ [J53(Rldrd19)] or $200 \mu \mathrm{g}$ carbenicillin $\mathrm{ml}^{-1}$ [J53(RSF1030)]. All strains were routinely grown in NBY broth $-E$. coli at $37^{\circ} \mathrm{C}$ and Corynebacterium strains at $25^{\circ} \mathrm{C}$. Samples were radioisotopically labelled in medium N (Vidaver, 1967) containing $1 \%(\mathrm{w} / \mathrm{v})$ yeast extract (Difco).

Bacteriocin production and assay conditions were as described by Gross \& Vidaver (1979).

Labelling procedures. Exponential phase cultures of corynebacteria grown in supplemented medium $\mathrm{N}$ broth were subcultured to $5 \times 10^{7}$ bacteria $\mathrm{ml}^{-1}$ in medium containing $5 \mu \mathrm{Ci}\left[{ }^{3} \mathrm{H}\right]$ thymidine $\mathrm{ml}^{-1}(52 \mathrm{Ci}$ $\mathrm{mmol}^{-1}$; ICN Chemical and Radioisotope Division, Irvine, Calif., U.S.A.). Escherichia coli was grown using the same medium and procedures as described for Corynebacterium, except that $1 \mu \mathrm{Ci}\left[{ }^{14} \mathrm{C}\right]-$ thymine $\mathrm{ml}^{-1}$ (65 $\mathrm{mCi} \mathrm{mmol}{ }^{-1}$; ICN Chemical and Radioisotope Division) was added in the presence of $250 \mu \mathrm{g}$ 2-deoxyadenosine $\mathrm{ml}^{-1}$.

Cell lysis and plasmid isolation. Bacteria were grown in $30 \mathrm{ml}$ medium to between $2 \times 10^{8}$ and $6 \times 10^{8}$ bacteria $\mathrm{ml}^{-1}$. Corynebacterium cells were lysed by the method of Chassy et al. (1976), and $E$. coli by the method of Currier \& Nester (1976). All plasmids were isolated by the Currier \& Nester (1976) procedure, as modified by Gross et al. (1979). Cells lysed with Sarkosyl NL30 (final concn $1 \%$ (v/v); ICN Pharmaceuticals, Plainview, N.Y., U.S.A.) were then sheared in $4 \mathrm{ml}$ amounts and denatured with alkali. Denatured DNA was removed and plasmid DNA was concentrated as described by Gross et al. (1979).

Agarose gel electrophoresis. Ethanol-precipitated DNA, pelleted by centrifuging at $12100 \mathrm{~g}$ for $20 \mathrm{~min}$, was electrophoresed in $\mathbf{0 . 7 \%}$ (w/v) agarose (Sea Kem, Marine Colloids, Rockland, Me., U.S.A.) according to the method of Meyers et al. (1976). After resuspension of the plasmid pellet in $200 \mu$ l of a dye solution (Gonzales \& Vidaver, 1979), 5 to $30 \mu \mathrm{l}$ of the sample was applied per well and electrophoresed for $3.5 \mathrm{~h}$ with $40 \mathrm{~V}$ (approx. $5 \mathrm{~V} \mathrm{~cm}^{-1}$ ) supplied by a constant voltage power source; the dimensions of the gel were the same as described previously (Gross et al., 1979). Gels were stained with ethidium bromide $\left(1 \mu \mathrm{g} \mathrm{ml}^{-1}\right.$ in distilled water) for $1 \mathrm{~h}$ and visualized according to Hansen \& Olsen (1978). The average molecular mass was determined according to Meyers et al. (1976) by comparing the relative mobilities of Corynebacterium plasmids and plasmids RSF1030 [5.5 Mdal (Meyers et al., 1976)], RP1 [39 Mdal (Burkardt et al., 1978)] and R1 [62 Mdal (Meyers et al., 1976)].

Dye-buoyant density equilibrium centrifugation. $\mathrm{CsCl}$ /ethidium bromide buoyant density centrifugation of $\left[{ }^{3} \mathrm{H}\right] \mathrm{DNA}$ was done as described by Gross et al. (1979).

Sucrose gradient centrifugation. Plasmids to be centrifuged in neutral or alkaline sucrose gradients were first banded in $\mathrm{CsCl}$ /ethidium bromide density gradients as above and then recovered by syringe (20-gauge needle). Ethidium bromide was extracted with propan-2-ol (saturated with $\mathrm{CsCl}$ ); the $\mathrm{CsCl}$ was removed by dialysis against TES buffer (0.02 M-Tris, $0.005 \mathrm{~m}$-EDTA, 0.5 M-NaCl; pH 7.4). After dialysis, ${ }^{14} \mathrm{C}$-labelled RP1 was mixed with each of the ${ }^{3} \mathrm{H}$-labelled Corynebacterium plasmids at approximately a $1: 3$ ratio of radioactivity. The plasmid mixture was brought to $0.3 \mathrm{M}$-sodium acetate (final concn), carrier transfer RNA (Sigma) was added to $30 \mu \mathrm{g} \mathrm{ml}^{-1}$ (final concn) and 2 vol. cold $\left(-20^{\circ} \mathrm{C}\right) 95 \%$ ethanol was added to precipitate the DNA. The precipitated DNA was recovered as above and suspended in $200 \mu 1$ TES buffer. Samples were layered on to a 5 to $20 \%$ neutral sucrose gradient containing TES buffer and the gradients were centrifuged at 39000 rev. $\mathrm{min}^{-1}$ at $20^{\circ} \mathrm{C}$ in a Spinco SW50.1 rotor (Shipley \& Olsen, 1975). The plasmids from $C$. nebraskense 298 and $C$. poinsettiae no. 13 were centrifuged for $80 \mathrm{~min}$. and that from $C$. michiganense 156-2 for $60 \mathrm{~min}$. Gradients were fractionated (125 $\mu \mathrm{l}$ per fraction) from the top using an ISCO model 640 density gradient fractionator (Instrumentation Specialties Co., Lincoln, Nebr., U.S.A.). Triton X-100/ toluene/Liquifluor scintillant (Van Etten et al., 1973) was then added to each fraction and ${ }^{3} \mathrm{H}$ and ${ }^{14} \mathrm{C}$ activity were measured. Sedimentation velocity and molecular weights of the Corynebacterium plasmids were calculated according to Studier (1965) and Clowes (1972) using $\left[{ }^{14} \mathrm{C}\right] \mathrm{RP} 1$ as a standard. Sedimentation coefficients for open circular (OC) and covalently closed circular (CCC) RP1 DNA were as reported by Grinsted et al. (1972).

Log-linear alkaline sucrose gradients, run on a Spinco SW41 rotor (Brakke \& Van Pelt, 1970), contained $0.3 \mathrm{M}-\mathrm{NaOH}, 0.05 \mathrm{M}-\mathrm{NaCl}$ and $0.05 \mathrm{M}-\mathrm{EDTA}$. The ${ }^{3} \mathrm{H}$-labelled Corynebacterium plasmid(s) were mixed with ${ }^{14} \mathrm{C}$-labelled plasmids RSF1030 and RP1. These samples $(500 \mu \mathrm{l})$ were applied to the SW41 alkaline gradient and centrifuged at $37000 \mathrm{rev} . \mathrm{min}^{-1}$ for $150 \mathrm{~min}$ at $6^{\circ} \mathrm{C}$. Gradients were fractionated ( $250 \mu 1$ per fraction) and 


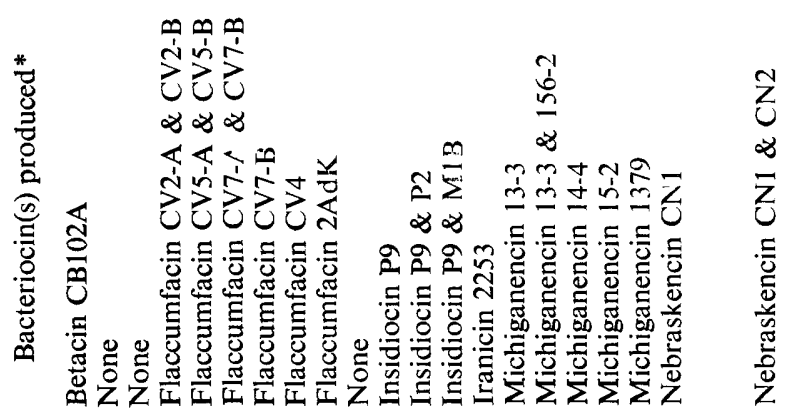

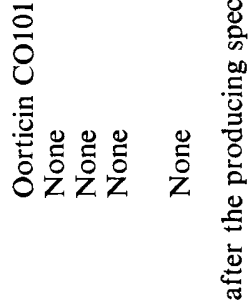

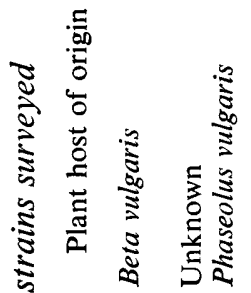
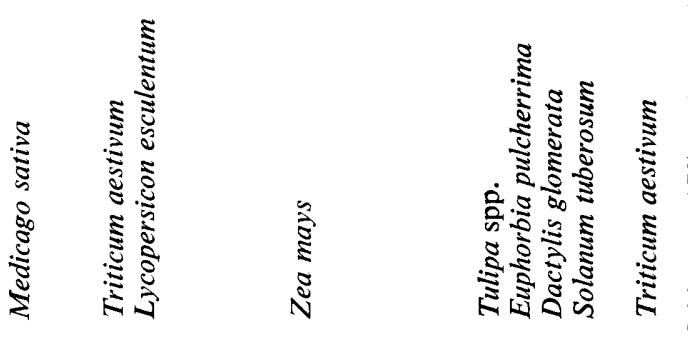

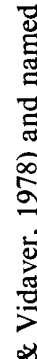

苛
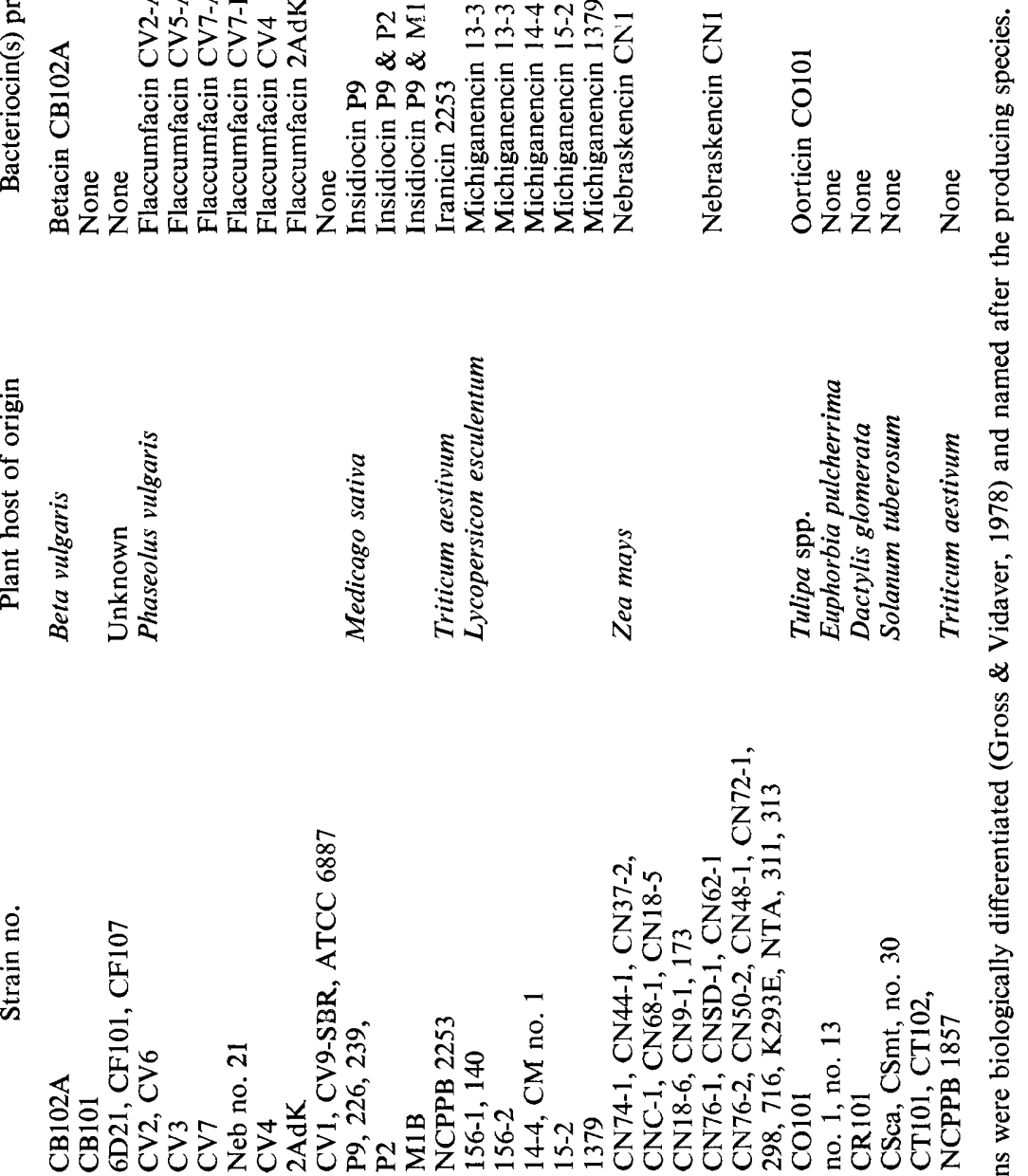

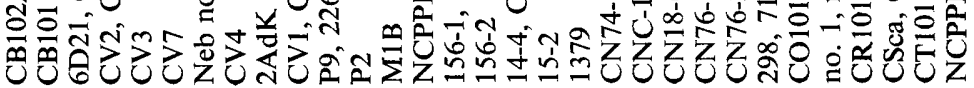
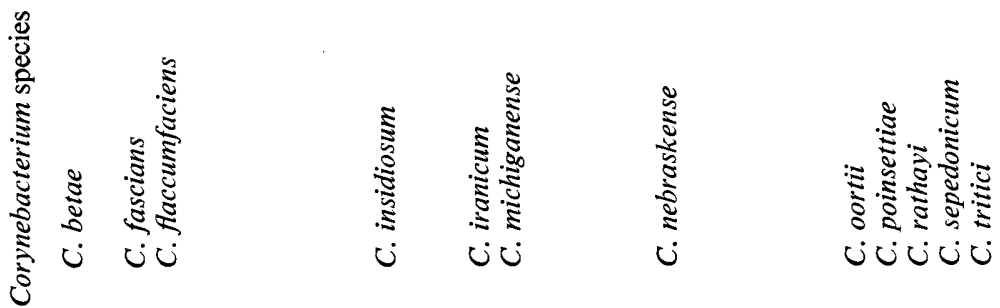


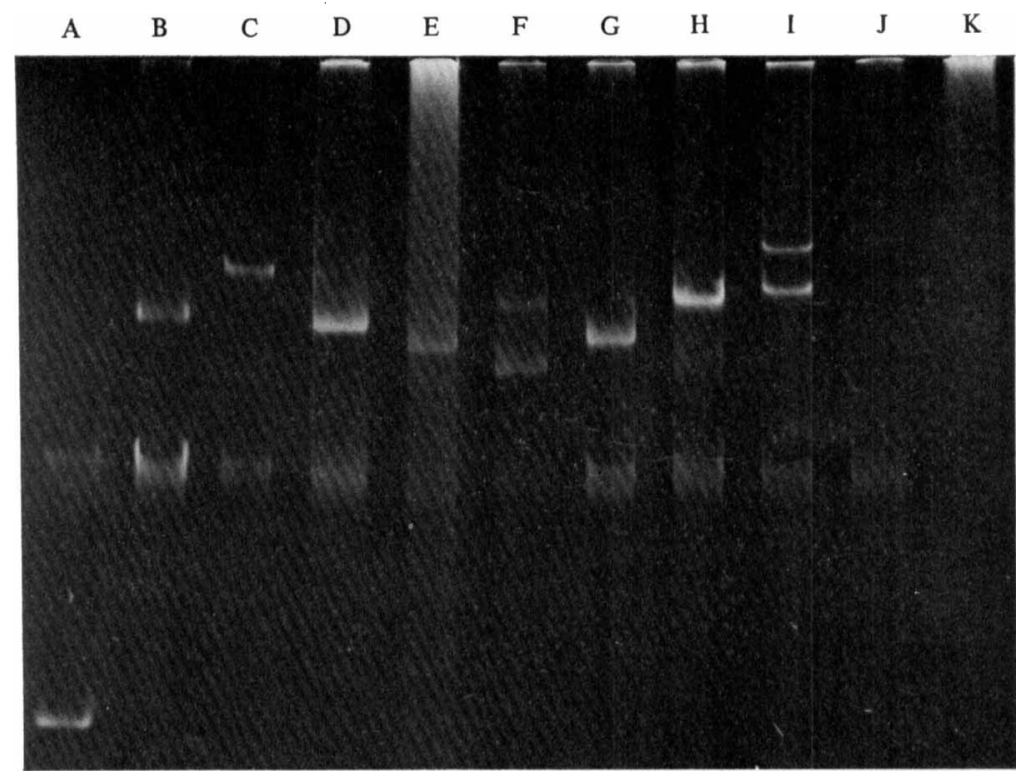

Fig. 1. Agarose gel electrophoresis of plasmids from phytopathogenic Corynebacterium species and reference plasmids from E. coli. Reference plasmids are: A, RSF1030 (5.5 Mdal); B, RP1 (39 Mdal); C, R1drd19 (62 Mdal). Plasmid profiles of Corynebacterium strains are: D, C. nebraskense 298 (34 Mdal); E, C. insidiosum M1B (53 and $28 \mathrm{Mdal}) ; \mathrm{F}, C$. michiganense CM no. 1 (42 and 25 Mdal); G, C. sepedonicum no. 30 (33 Mdal); H, C. poinsettiae no. 13 (44 Mdal); I, C. oortii CO101 (68 and $46 \mathrm{Mdal}) ; \mathrm{J}$, C. fascians CF107 (77 Mdal); K, C. tritici CT102 (35 Mdal). Chromosomal fragments are seen as a common band.

${ }^{3} \mathrm{H}$ and ${ }^{14} \mathrm{C}$ activity were measured as described for neutral sucrose gradients. The molecular weights of ${ }^{3} \mathrm{H}$-labelled plasmids from corynebacteria were determined by their sedimentation rates relative to ${ }^{14} \mathrm{C}$ labelled RSF1030 and RP1 plasmids in the log-linear gradients.

Plasmid isolated from C. poinsettiae no. 13 by the Currier \& Nester (1976) procedure, as modified above, was directly applied to Spinco SW41 log-linear alkaline sucrose gradients and centrifuged as above. During fractionation the $A_{254}$ was monitored on an ISCO model UA-4 absorbance monitor (Instrumentation Specialties Co.) and then ${ }^{3} \mathrm{H}$ was measured.

\section{RESULTS}

\section{Cell lysis and plasmid isolation}

The procedure of Chassy et al. (1976) gave clear lysates of all Corynebacterium species except $C$. tritici, $C$. iranicum, $C$. rathayi and $C$. fascians. However, these latter species lysed sufficiently to permit recovery of low levels of plasmid from all strains of the species except C. iranicum 2253, in which no plasmid was detected. Lysis was not improved by exposure to penicillin $\mathrm{G}$ (tested at 50 or $200 \mu \mathrm{g} \mathrm{ml}^{-1}$ ) for $3 \mathrm{~h}$ prior to cell harvest (unpublished results).

The modified Currier \& Nester (1976) procedure enabled the isolation of plasmids from nine species of Corynebacterium (Table 2), reducing the amount of chromosomal DNA to about the same as that of plasmid DNA (Figs 1 and 2). This procedure was superior to other methods tested. Plasmids from C. nebraskense 298 and C. michiganense 156-2 were not isolated by the cleared lysate procedure (Clewell \& Helinski, 1969), and low, variable amounts of plasmid were isolated from these strains using the procedure of Guerry et al. (1973).

\section{Plasmid characterization}

Incorporation of $\left[{ }^{3} \mathrm{H}\right]$ thymidine into DNA varied between strains and species. For example, C. nebraskense 298 incorporated less than half the amount of ${ }^{3} \mathrm{H}$ incorporated by 


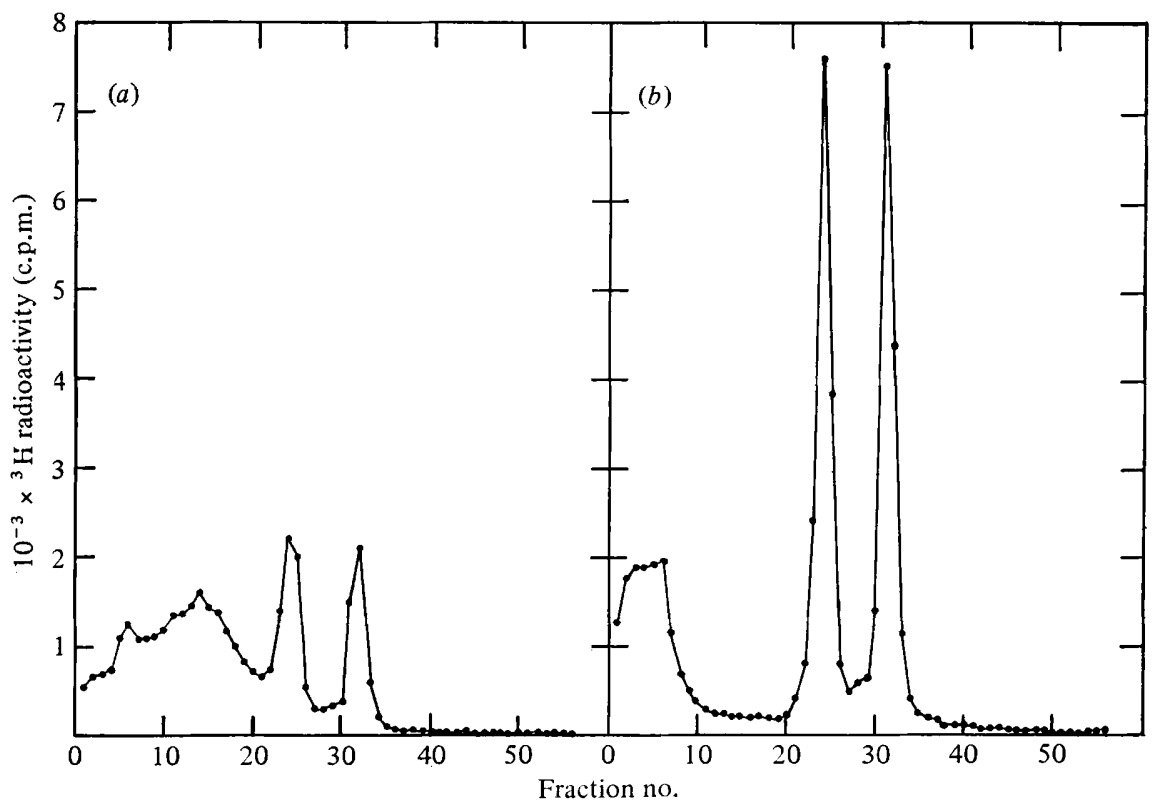

Fig. 2. Caesium chloride/ethidium bromide density gradient profiles of [ $\left.{ }^{3} \mathrm{H}\right] \mathrm{DNA}$ of $C$. nebraskense $298(a)$ and $C$. michiganense 156-2 (b). After reaching equilibrium the gradient was fractionated from the bottom. For both strains fraction 24 contained the plasmid DNA peak and fraction 31 or 32 contained the chromosomal DNA peak.

Table 2. Plasmids of phytopathogenic Corynebacterium species

\begin{tabular}{|c|c|c|c|}
\hline $\begin{array}{c}\text { Corynebacterium } \\
\text { species* }\end{array}$ & $\begin{array}{c}\text { Total } \\
\text { no. of } \\
\text { strains } \\
\text { surveyed }\end{array}$ & Strains containing plasmid(s) & $10^{-6} \times$ Calculated mol. wt $\dagger$ \\
\hline C. insidiosum & 5 & $\begin{array}{l}239 \\
\text { P2, P9, 226, M1B }\end{array}$ & $\begin{array}{l}23( \pm 2 \cdot 0), 28( \pm 2 \cdot 0), 53( \pm 4 \cdot 9) \\
28( \pm 2 \cdot 0), 53( \pm 4 \cdot 9)\end{array}$ \\
\hline C. michiganense & 7 & $\begin{array}{l}1379 \\
C M \text { no. } 1 \\
15-2 \\
14-4 \\
156-1,156-2,140\end{array}$ & $\begin{array}{l}24( \pm 2 \cdot 6), 32( \pm 2 \cdot 2) \\
25( \pm 3 \cdot 3), 42( \pm 5 \cdot 0) \\
31( \pm 2 \cdot 6) \\
38( \pm 4 \cdot 7) \\
52( \pm 2 \cdot 4)\end{array}$ \\
\hline C. sepedonicum & 3 & CSmt, no. 30 & $33( \pm 3 \cdot 0)$ \\
\hline C. nebraskense & 22 & $\begin{array}{l}\text { 298, 173, NTA, } \\
\text { CN48-1, CN68-1 }\end{array}$ & $34( \pm 1 \cdot 3)$ \\
\hline C. tritici & 3 & $\begin{array}{l}\text { CT101, CT102, } \\
\text { NCPPB } 1857\end{array}$ & $35( \pm 2 \cdot 1)$ \\
\hline C. poinsettiae & 2 & no. 1 , no. 13 & $44( \pm 3 \cdot 4)$ \\
\hline C. oortii & 1 & CO101 & $46( \pm 2 \cdot 8), 68( \pm 4 \cdot 2)$ \\
\hline C. rathayi & 1 & CR101 & $47( \pm 4 \cdot 3)$ \\
\hline C. fascians & 3 & 6D21, CF101, CF107 & $77( \pm 6 \cdot 3)$ \\
\hline
\end{tabular}

* Corynebacterium betae (2 strains), C. flaccumfaciens (10 strains) and C. iranicum (1 strain) did not contain plasmids.

$\dagger$ Determined by electrophoretic separation on agarose gels as described in the text. All values represent averages of four to eight replications for each plasmid-containing strain. Numbers in parentheses are the standard deviation of the molecular weight determined for each plasmid. 
(a) C. insidiosum

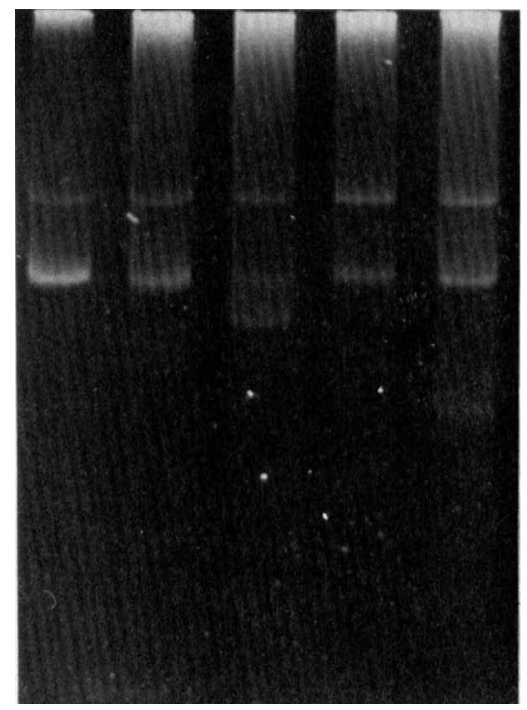

(b) C. michiganense

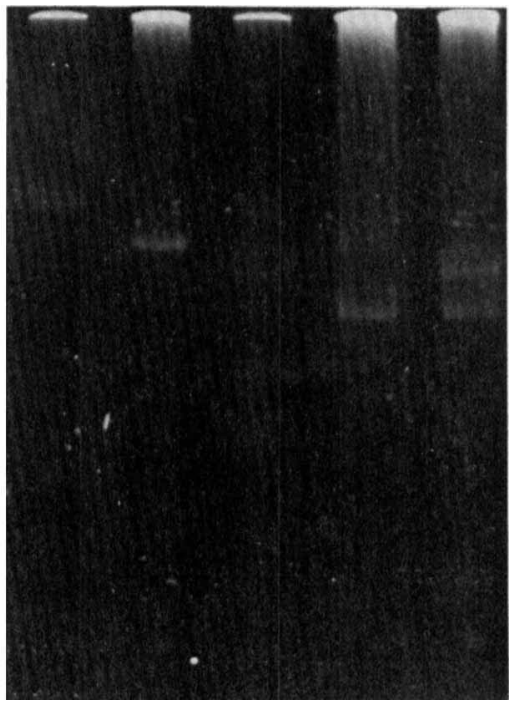

Fig. 3. Similarity of plasmid size and number within $C$. insidiosum (a) and diversity in $C$. michiganense $(b)$. Before agarose gel electrophoresis, plasmids were banded on $\mathrm{CsCl} /$ ethidium bromide density gradients.

(a) C. insidiosum strains (left to right) are: M1B, P2, 239, 226 and P9. All strains had a 53 and 28 Mdal plasmid; strain 239 also had a 23 Mdal plasmid. The lowest band seen for P9 consists of residual chromosomal DNA fragments.

(b) C. michiganense strains (left to right) are: 140 (52 Mdal), 14-4 (38 Mdal), 15-2 (31 Mdal), CM no. 1 (42 and $25 \mathrm{Mdal}$ ) and 1379 (32 and $24 \mathrm{Mdal})$.

an equal number of cells of $C$. michiganense 156-2. However, $\left[{ }^{3} \mathrm{H}\right]$ thymidine served as a good source of radioactive precursor for all species, as determined by the activity in plasmid peaks from a $15 \mathrm{ml}$ culture (labelled as in Methods) analysed by $\mathrm{CsCl} /$ ethidium bromide gradient centrifugation (Fig. 2).

Strains from nine phytopathogenic Corynebacterium species had one to three plasmids ranging from 23 to $77 \mathrm{Mdal}$ (Table 2, Fig. 1). All C. fascians strains contained the largest plasmid, whereas $C$. insidiosum 239 had the smallest. Only strain 239 had three different plasmids, although a number of species and strains contained two plasmids. All strains within some species (e.g. C. michiganense and C. insidiosum) contained at least one plasmid; only five of $22 \mathrm{C}$. nebraskense strains contained plasmids. Bacteriocin production did not correlate with the presence or absence of plasmids (Table 1). For example, C. nebraskense strains with and without plasmids produced nebraskencin $\mathrm{CN} 2$, while strains 173 and CN68-1 had a plasmid but did not produce this bacteriocin. Corynebacterium iranicum 2253 that apparently lacked a plasmid produced iranicin 2253 . Some species, such as $C$. insidiosum, appeared to be relatively homogeneous in the number and size of plasmids, whereas others, such as $C$. michiganense, contained diverse plasmids (Fig. 3). All five $C$. insidiosum strains had two plasmids that appeared to be common (Fig. $3 a$ ), whereas five strains of $C$. michiganense had plasmids differing in size and number (Fig. $3 b$ ).

Covalently closed circular (CCC) DNA is shown in neutral and alkaline sucrose gradients (Figs 4 and 5). Plasmid RP1 was of a similar size to the plasmids from C. nebraskense 298, $C$. poinsettiae no. 13 and C. michiganense 156-2. Grinsted et al. (1972) determined sedimentation coefficients of $43 \mathrm{~S}$ and $62 \mathrm{~S}$ for open circular (OC) and CCC RP1 DNA, respectively. Although the plasmid from $C$. nebraskense 298 appeared to be smaller than RP1 by its relative mobility on agarose gels, in neutral gradients it had sedimentation coefficients of $43 \mathrm{~S}_{\mathrm{oo}}$ and $60 \mathrm{~S}_{\mathrm{Cco}}$ (Fig. 4) corresponding to a size similar to RP1 (Table 3). The plasmids from 


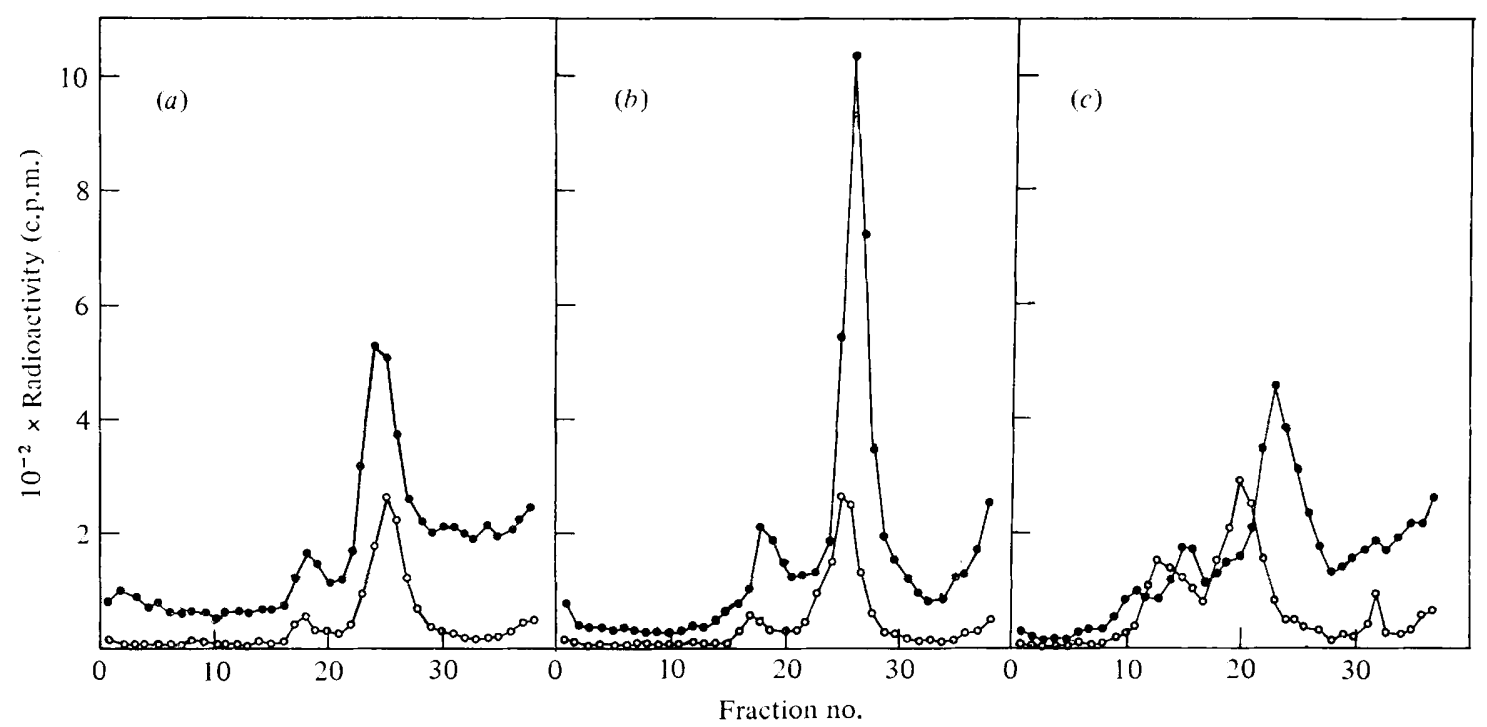

Fig. 4. Sedimentation of plasmids in a 5 to $20 \%$ neutral sucrose gradient. ${ }^{3} \mathrm{H}$-Labelled plasmids (O) from C. nebraskense 298 (a), C. poinsettiae no. 13 (b) and C. michiganense 156-2 (c) were cosedimented with $\left.{ }^{14} \mathrm{C}\right] \mathrm{RP1}(O)$ for $80 \mathrm{~min}(a, b)$ or $60 \mathrm{~min}(c)$ at $39000 \mathrm{rev} \cdot \mathrm{min}^{-1}$ (Spinco SW50.1). Samples were fractionated $(125 \mu \mathrm{l}$ per fraction) from the top of the gradient. Sedimentation coefficients, calculated using $S_{O C}=43 S$ and $S_{C C C}=62 S$ for RP1, are: $C$. nebraskense 298, fraction $18=S_{\mathrm{OC}}=43 \mathrm{~S}$, fraction $24=\mathrm{S}_{\mathrm{CCC}}=60 \mathrm{~S} ; C$. poinsettiae no. 13 , fraction $18=\mathrm{S}_{\mathrm{Oc}}=46 \mathrm{~S}$, fraction $26=\mathrm{S}_{\mathrm{CCC}}=65 \mathrm{~S}: C$. michiganense 156-2, fraction $15=\mathrm{S}_{\mathrm{OC}}=50 \mathrm{~S}$, fraction $23=$ $\mathrm{S}_{\mathrm{CCC}}=71 \mathrm{~S}$. Calculated molecular weights are listed in Table 3.

Table 3. Comparison of plasmid molecular weights determined by different methods

$\begin{array}{lcccc}\text { Corynebacterium species } & \begin{array}{c}\text { Gel } \\ \text { electro- } \\ \text { phoresis* }\end{array} & \text { OC } & \text { CCC } & \begin{array}{c}\text { Neutral } \\ \text { gradient } \dagger\end{array} \\ \text { C. nebraskense 298 } & 34 & 40 & 37 & 39 \\ \text { C. poinsettiae no. 13 } & 44 & 47 & 47 & 47 \\ \text { C. michiganense 156-2 } & 52 & 61 & 63 & 56 \\ \text { C. } \text { oortii CO101 } & 46,68 & \text { ND } & \text { ND } & 47,73\end{array}$

ND, Not determined.

* Calculated from relative electrophoretic migrations in $0.7 \%$ agarose gels: reference plasmids were $5 \cdot 5$, 39 and 62 Mdal.

$\uparrow$ Determined from sedimentation coefficients using the $S_{O C}$ and $S_{C C C}$ of RP1 (43S and 62S, respectively).

$\$$ Determined from relative sedimentation of RP1 (39 Mdal) and RSF1030 (5.5 Mdal) in log-linear alkaline sucrose gradients.

strains $C$. poinsettiae no. 13 and $C$. michiganense $156-2$ also had sedimentation coefficients indicative of a larger size than originally calculated from agarose gels (Table 3). In alkaline log-linear sucrose gradients the CCC DNA from Corynebacterium strains sedimented at a rate similar to RP1. In a strain containing two plasmids, $C$. oortii CO101, the larger plasmid (estimated at $73 \mathrm{Mdal}$ ) sedimented more rapidly than RSF1030 and RP1. Molecular weights for plasmids from four species (Table 3), calculated from sedimentation profiles in alkaline sucrose gradients (Fig. 5), were similar to those calculated by either gel electrophoresis or by sedimentation in neutral sucrose gradients. These results are strong evidence that the bulk of plasmid DNA from corynebacteria is CCC. 


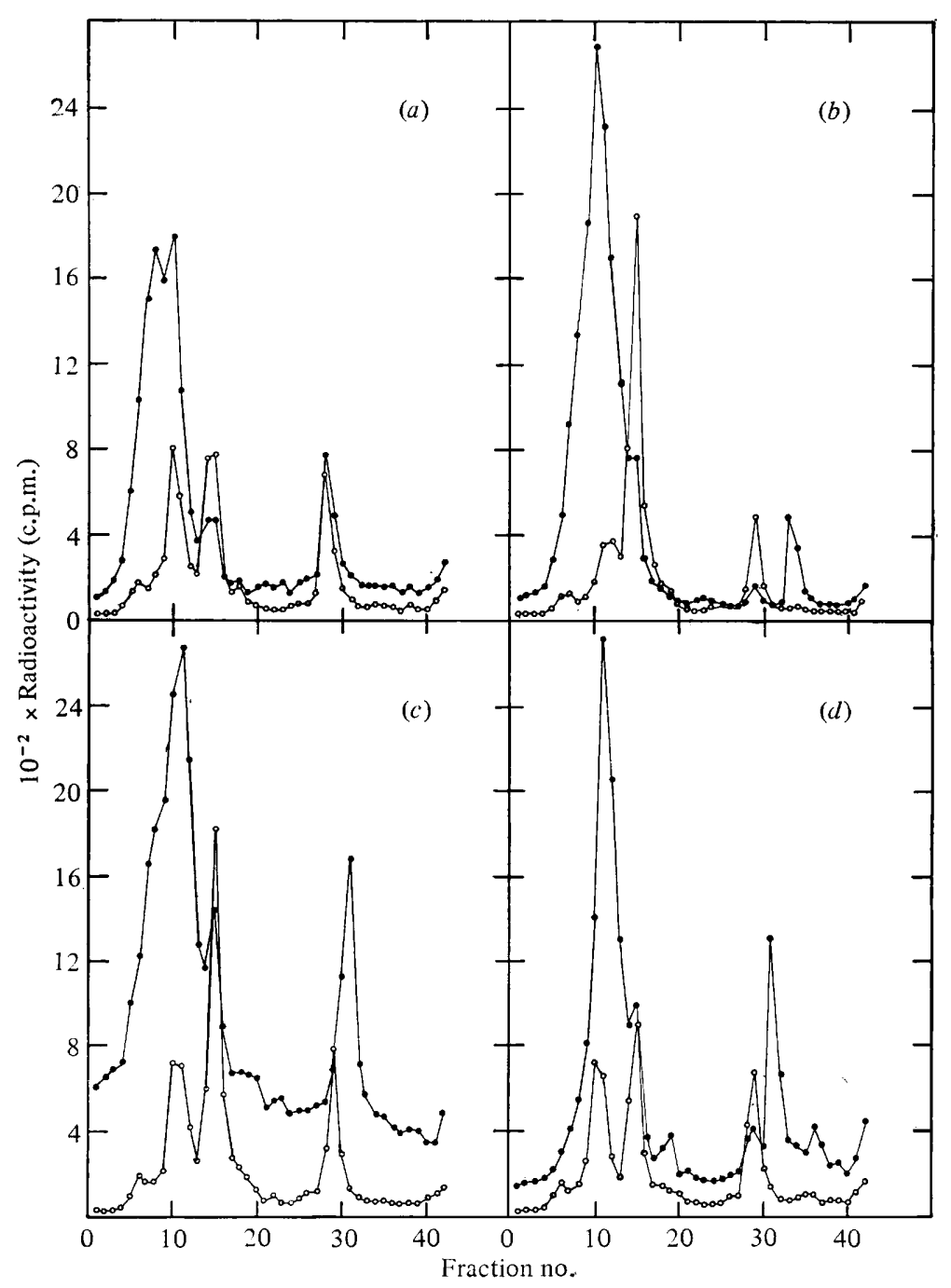

Fig. 5. Alkaline sucrose gradient profiles of ${ }^{3} \mathrm{H}$-labelled plasmids (O) from C. nebraskense 298 (a), C. michiganense 156-2 (b), C. poinsettiae no. $13(c)$ and $C$. oortii CO101 (d) co-sedimented with reference ${ }^{14} \mathrm{C}$-labelled plasmids (O) RSF1030 (fraction 15) and RP1 [fraction 28 (with $C$. nebraskense 298) and fraction 29 (with the other three Corynebacterium strains)]. Single plasmid peaks were seen for $C$. nebraskense 298 (fraction 28), C. michiganense 156-2 (fraction 33), and C. poinsettiae no. 13 (fraction 31 ); two plasmid peaks (fractions 31 and 36 ) were seen for $C$. oortii CO101. Samples were fractionated $(250 \mu \mathrm{l}$ per fraction) from the top of the gradient. Radioactivity in fractions 2 to 13 represents residual linear DNA and open circular plasmid DNA. In all cases less than $10 \%$ of ${ }^{14} \mathrm{C}$ was counted in the ${ }^{3} \mathrm{H}$ window. Plasmid molecular weights (Table 3 ) were determined by comparative sedimentation to RSF1030 and RP1 through these log-linear gradients centrifuged for $150 \mathrm{~min}$ in a Spinco SW41 rotor.

Figure 6 shows a sedimentation profile of a plasmid preparation from C.poinsettiae no. 13 through an alkaline log-linear sucrose gradient. In contrast to the gradients shown in Fig. 5, plasmids had not previously been banded on $\mathrm{CsCl}$ /ethidium bromide gradients. Such gradients are useful for the preparative separation of plasmids from chromosomal DNA in sufficient quantity to allow detection by measurement of $A_{254}$. The purified plasmid was obtained in large quantity $\left(A_{254}\right.$ approx. 0.4$)$ from a $5 \mathrm{ml}$ culture grown to about $5 \times 10^{8}$ bacteria $\mathrm{ml}^{-1}$. 


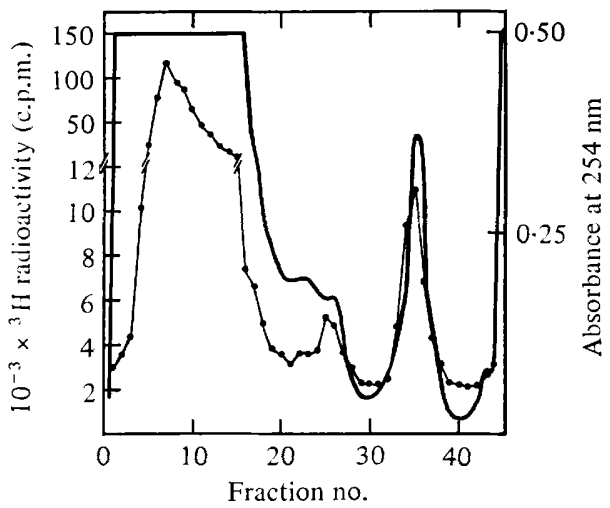

Fig. 6. Correspondence of peaks of absorbance $(-)$ and ${ }^{3} \mathrm{H}$-labelled plasmid (O) from $C$. poinsettiae no. 13 in a log-linear alkaline sucrose gradient. The plasmid was isolated as described in the text and then centrifuged without prior banding on $\mathrm{CsCl}$ /ethidium bromide gradients. Samples were centrifuged at $37000 \mathrm{rev} . \mathrm{min}^{-1}$ for $150 \mathrm{~min}$ in a Spinco SW41 rotor. Samples (250 $\mu \mathrm{l}$ per fraction) were collected from the top of the tube and monitored at $254 \mathrm{~nm}$. The plasmid peak was in fraction 35. Residual linear DNA and open circular plasmid DNA is visible at the top of the alkaline gradient.

\section{DISCUSSION}

Plasmids of moderate size (approximately 23 to $77 \mathrm{Mdal}$ ) were isolated from strains representing nine species of phytopathogenic corynebacteria. The size and number of plasmids in plasmid-containing strains of $C$. nebraskense and $C$. insidiosum were limited; strains having apparently identical plasmids, however, often varied in bacteriocin production, colony morphology, pigmentation and virulence. In contrast, seven different plasmids were distributed among seven $C$. michiganense strains. Some species, such as $C$. flaccumfaciens, had no detectable plasmids. Thus, there are considerable differences in plasmid size and number among the phytopathogenic corynebacteria.

The function of the Corynebacterium plasmids is unknown but seems unrelated to antibiotic resistance, production of bacteriocins or virulence (Gross \& Vidaver, unpublished results). Hydrocarbon breakdown is an important plasmid borne-trait in many Pseudomonas species (Gunsalus et al., 1975). Some Corynebacterium species also degrade hydrocarbons (Veldkamp, 1970) and this ability may be plasmid-determined. Similarly, plasmids in Agrobacterium tumefaciens transform plant cells to form crown gall on a number of plant hosts (Marx, 1979); C. fascians also forms galls, and again, this function may be plasmidborne. The common presence of plasmids in Corynebacterium suggests an important function in their survival, possibly in relation to pathological effects.

The procedures for cell lysis and plasmid isolation were adaptable and convenient for all phytopathogenic Corynebacterium strains. Despite poor lysis by all strains of $C$. tritici, $C$. iranicum, $C$. rathayi and $C$. fascians, plasmids were nevertheless isolated in sufficient quantity to be readily visible on agarose gels.

Plasmid copy number could be approximated by determining the ratio of plasmid DNA to total DNA from $\mathrm{CsCl}$ /ethidium bromide gradients (calculated from radioactivity in the cleared lysate subsamples before phenol treatment). Assuming a genome size of $2 \times 10^{9}$ daltons (Bak et al., 1970) it was estimated that there were approximately 1 to 2 copies per cell of each plasmid for strains $C$. nebraskense $298, C$. poinsettiae no. 13, C. michiganense 156-2 and C. oortii CO101.

Plasmid size and number were readily determined by electrophoretic separation in agarose gels, as they have been for other Gram-negative and Gram-positive bacteria. Meyers et al. (1976) estimated less than $10 \%$ error in determining plasmid size: linearity of plasmid 
migration in $0.7 \%$ agarose gels has since been reported for plasmids up to $140 \mathrm{Mdal}$ (Hansen \& Olsen, 1978). In this study, a linear standard curve for plasmids RSF1030, RP1 and $\mathrm{R} 1$ enabled rapid and accurate determination of plasmid size. OC DNA migrates considerably more slowly than CCC DNA and was not observed if plasmids were freshly prepared and properly stored (Meyers et al., 1976). The estimated plasmid size in strains from different Corynebacterium species using neutral and alkaline sucrose gradient centrifugation was similar to those calculated by electrophoresis, suggesting that the DNA was in the CCC configuration. In addition, satellite DNA from $\mathrm{CsCl}$ /ethidium bromide gradients was of identical mobility to plasmids from the crude preparations; these results also were indicative of CCC DNA (Hansen \& Olsen, 1978). A small over-estimation in size was calculated from the neutral sucrose gradients, resulting in part from a larger calculated mass (40 Mdal) and sedimentation coefficient for RP1 in neutral sucrose gradients (Grinsted et al., 1972) relative to the mass now reported for RP1 (39 Mdal; Burkardt et al., 1978).

Alkaline sucrose gradients have been used primarily as a method of isolating plasmids (Clowes, 1972) and only sparingly to determine plasmid size (Nuti et al., 1977). But by using log-linear alkaline sucrose gradients, as reported here, direct estimations of molecular weight could be obtained by comparison with the sedimentation of internal reference plasmids. Such gradients gave reproducible, sharp plasmid bands and molecular weights that agreed with those estimated from agarose gels. More significantly, alkaline sucrose gradients are an efficient and reliable means of isolating plasmid DNA. Efficiency was shown by the recovery of plasmids from crude plasmid preparations. Reliability was evident from the reproducible and predictable banding and relative positions of the plasmids as seen, for example, by the physical separation of the two plasmids of $C$. oortii CO101. If plasmids were sufficiently divergent in size, single purified plasmid species could be obtained preparatively.

We thank Dr C. F. Gonzalez for consultations and assistance on plasmid analyses. The technical help of Mark Widger is gratefully acknowledged. Published as Paper no. 5736, Journal Series, Nebraska Agricultural Experiment Station. Part of this work was supported by United States Department of Agriculture-regional research funds for project NC-135.

\section{REFERENCES}

Bak, A. L., Christiansen, C. \& Stenderup, A. (1970). Bacterial genome sizes determined by DNA renaturation studies. Journal of General Microbiology 64, 377-380.

Brakke, M. K. \& Van Pelt, N. (1970). Linear-log sucrose gradients for estimating sedimentation coefficients of plant viruses and nucleic acids. Analytical Biochemistry 38, 56-64.

Burkardt, H. J., Mattes, R., Puhler, A. \& HeumanN, W. (1978). Electron microscopy and computerized evaluation of some partially denatured group $\mathrm{P}$ resistance plasmids. Journal of General Microbiology 105, 51-62.

Chassy, B. M., Gibson, E. \& Giuffrida, A. (1976). Evidence for extrachromosomal elements in Lactobacillus. Journal of Bacteriology 127, 15761578.

Clewell, D. B. \& Helinski, D. R. (1969). Supercoiled circular DNA-protein complex in Escherichia coli: purification and induced conversion to an open circular DNA form. Proceedings of the National Academy of Sciences of the United States of America 62, 1159-1166.

Clowes, R. C. (1972). Molecular structure of bacterial plasmids. Bacteriological Reviews 36, $361-405$.

Currier, T. C. \& Nester, E. W. (1976). Isolation of covalently closed circular DNA of high molecular weight from bacteria. Analytical Biochemistry 76, 431-441.

ECHANDI, E. \& SUN, M. (1973). Isolation and characterization of a bacteriophage for the identification of Corynebacterium michiganense. Phytopathology 63, 1398-1401.

Gonzalez, C. F. \& Vidaver, A. K. (1979). Bacteriocin, plasmid and pectolytic diversity in Pseudomonas cepacia of clinical and plant origin. Journal of General Microbiology 110, 161-170.

Grinsted, J., SAunders, J. R., INGRam, L. C., Sykes, R. B. \& Richmond, M. H. (1972). Properties of an $\mathbf{R}$ factor which originated in Pseudomonas aeruginosa 1822. Journal of Bacteriology 110, 529-537.

Gross, D. C. \& Vidaver, A. K. (1979). Bacteriocins of phytopathogenic Corynebacterium species. Canadian Journal of Microbiology 25, 367-374.

Gross, D. C., Vidaver, A. K. \& Klucas, R. V. (1979). Plasmids, biological properties and 
efficacy of nitrogen fixation in Rhizobium japonicum strains indigenous to alkaline soils. Journal of General Microbiology 114, 257-266.

Guerry, P., LeBlanc, D. J. \& Falkow, S. (1973). General method for the isolation of plasmid deoxyribonucleic acid. Journal of Bacteriology 116, $1064-1066$.

Gunsalus, I. C., Hermann, M., Toscano, W. A., JR, KATZ, D. \& GARY, G. K. (1975). Plasmids and metabolic diversity. In Microbiology - 1974, pp. 207-212. Edited by D. Schlessinger. Washington: American Society for Microbiology.

Hansen, J. B. \& OLSEN, R. H. (1978). Isolation of large bacterial plasmids and characterization of the P2 incompatibility group plasmids pMG1 and pMG5. Journal of Bacteriology 135, 227-238.

LAZAR, I. (1968). Serological relationships of corynebacteria. Journal of General Microbiology 52, 77-88.

Lelliotr, R. A. (1966). The plant pathogenic coryneform bacteria. Journal of Applied Bacteriology 29, 114-118.

MARX, J. L. (1979). Crown gall disease: nature as genetic engineer. Science 203, 254-255.

Meyers, J. A., SANChez, D., Elwell, L. P. \& FALKow, S. (1976). Simple agarose gel electrophoretic method for the identification and characterization of plasmid deoxyribonucleic acid. Journal of Bacteriology 127, 1529-1537.

Nuti, M. P., Ledeboer, A. M., LePidi, A. A. \& SCHILPEROORT, R. A. (1977). Large plasmids in different Rhizobium species. Journal of General Microbiology 100, 241-248.
Shipley, P. L. \& OlSEN, R. H. (1975). Isolation of a nontransmissible antibiotic resistance plasmid by transductional shortening of $\mathbf{R}$ factor $\mathbf{R P 1}$. Journal of Bacteriology 123, 20-27.

Stark, M. P., Mandel, M. \& Murata, N. (1975). The phytopathogenic coryneform bacteria in the light of DNA base composition and DNA-DNA segmental homology. Journal of General and Applied Microbiology 21, 13-26.

STUdier, F. W. (1965). Sedimentation studies of the size and shape of DNA. Journal of Molecular Biology 11, 373-390.

TAGG, J. R., DaJani, A. S. \& Wannamaker, L. W. (1976). Bacteriocins of gram-positive bacteria. Bacteriological Reviews 40, 722-756.

Van Etten, J. L., Vidaver, A. K., Koski, R. K. \& SEMANCIK, J. S. (1973). RNA polymerase activity associated with bacteriophage $\phi 6$. Journal of Virology 12, 464-471.

VeldKAMP, H. (1970). Saprophytic coryneform bacteria. Annual Review of Microbiology 24, 209-240.

VIDAVER, A. K. (1967). Synthetic and complex media for the rapid detection of fluorescence of phytopathogenic pseudomonads: effect of the carbon source. Applied Microbiology 15, 15231524.

Vidaver, A. K. \& StarR, M. P. (1979). Phytopathogenic coryneform and related bacteria. In The Prokaryotes: Handbook on Habitats, Isolation, and Identification of Bacteria. Edited by M. P. Starr, H. Stolp, H. G. Truper, A. Balows \& H. G. Schlegel. New York: Springer-Verlag. 